\title{
MICROBE-MEDIATED PLANT-SOIL FEEDBACK CAUSES HISTORICAL CONTINGENCY EFFECTS IN PLANT COMMUNITY ASSEMBLY
}

\author{
Paul Kardol, ${ }^{1,3}$ Nelleke J. Cornips, ${ }^{1}$ Monique M. L. van Kempen, ${ }^{1}$ J. M. Tanja Bakx-Schotman, ${ }^{1}$ \\ AND Wim H. VAN DER PutTen ${ }^{1,2}$ \\ ${ }^{1}$ Netherlands Institute of Ecology (NIOO-KNAW), Centre for Terrestrial Ecology, P.O. Box 40, 6666 ZG Heteren, The Netherlands \\ ${ }^{2}$ Laboratory of Nematology, Wageningen University and Research Centre, P.O. Box 8123, 6700 ES Wageningen, The Netherlands
}

Abstract. Plant-soil feedback affects performance and competitive ability of individual plants. However, the importance of plant-soil feedback in historical contingency processes and plant community dynamics is largely unknown. In microcosms, we tested how six earlysuccessional plant species of secondary succession on ex-arable land induced plant-specific changes in soil community composition. Following one growth cycle of conditioning the soil community, soil feedback effects were assessed as plant performance in soil of their own as compared to soil from a mixture of the other five early-successional species. Performance was tested in monocultures and in mixed communities with heterospecific competition from midsuccessional species. The role of soil microorganisms was determined by isolating the microbial component from the soil community, re-inoculating microorganisms into sterilized substrate, and analyzing plant biomass responses of the early- and mid-successional species.

Plant-soil feedback responses of the early-successional species were negative and significantly increased when the plants were grown in a competitive environment with heterospecifics. In monocultures, three early-successional species experienced negative feedback in soil with a history of conspecifics, while all early-successional species experienced negative feedback when grown with interspecific competition. Interestingly, the nonnative forb Conyza canadensis showed the weakest soil feedback effect. Biomass production of the earlysuccessional plant species was profoundly reduced by the microbial inocula, most strongly when exposed to inocula of conspecific origin. Molecular characterization of the fungal and bacterial rhizosphere communities revealed a relationship between plant biomass production and the composition of the dominant fungal species. Furthermore, our results show that, in early secondary succession, the early-successional plant species induce changes in the soil microbial community composition that cause historical contingency effects in dominance patterns of mid-succession plant communities.

We conclude that feedback between early-successional plant species and soil microorganisms can play a crucial role in breaking dominance of early-successional plant communities. Moreover the influences on soil microorganism community composition influenced plant community dynamics in the mid-successional plant communities. These results shed new light on how feedback effects between plants and soil organisms in one successional stage result in a biotic legacy effect, which influences plant community processes in subsequent successional stages.

Key words: biotic legacy; community assembly; competition; denaturing gradient gel electrophoresis; $D G G E$; ex-arable land; historical contingency; microorganisms; plant-soil feedback; secondary succession.

\section{INTRODUCTION}

Nutrient and light availability are major driving forces of plant species replacements along successional trajectories (Tilman 1988, Grime 2001). At local scales, the interactions between plants and the soil community may strongly influence interspecific plant competition (Van der Putten and Peters 1997), resulting in enhanced rates of community development (Brown and Gange 1992, Van der Putten et al. 1993, Olff et al. 2000,

Manuscript received 23 March 2006; revised 9 October 2006; accepted 1 November 2006. Corresponding Editor: S. Y. Strauss.

${ }^{3}$ E-mail: p.kardol@nioo.knaw.nl
De Deyn et al. 2003). Soil community influences on plant community development may result from direct interactions between plant roots and pathogens (Bruehl 1987), herbivores (Brown and Gange 1990), and mutualists (Smith and Read 1997), as well as from indirect interactions with decomposing and mineralizing soil organisms (Bardgett and Shine 1999, Wardle et al. 2003, Hättenschwiler et al. 2005) or from belowground trophic chain reactions (Strong et al. 1996). Moreover plants may influence their own performance by changing the composition of their associated soil communities (Van der Putten et al. 1993, Bever 1994). Here we explore how these feedback effects may work out in early secondary succession and how they may contribute 
to historical contingency effects in later stages of plant community development.

The concept of ecological plant-soil feedback provides a powerful framework to study temporal plant community dynamics (Bever et al. 1997, Bever 2003). Plant-soil feedback involves two steps. First, plants change the composition of their associated soil community (Chanway et al. 1991, Kowalchuk et al. 2002). Second, these plant-induced changes in the soil community affect subsequent plant performance (Bever et al. 1997, Thrall et al. 1997). Through its effect on the composition of the soil community, a given plant species may either increase its own growth rate relative to other plant species (positive feedback) or decrease its own growth rate (negative feedback).

Although the nature of plant-soil feedback is still largely unknown, most evidence points toward plantspecific accumulation of beneficial or harmful microorganisms in the rhizosphere (Van der Putten 2003). Positive plant-soil feedback would be expected to lead to monocultures and to slow down the rate of succession (Bever 2003, Bonanomi et al. 2005). However, there is growing evidence that soil community feedback is commonly negative (Bever 1994, Bever et al. 1997, Olff et al. 2000, Klironomos 2002) and that negative feed backs may affect interspecific interactions (Van der Putten and Peters 1997, Bonanomi and Mazzoleni 2005). Depending on the dominance position of the involved plant species in the community, negative plantsoil feedback may either favor or disrupt species coexistence (Dobson and Crawley 1994, Bever 2003, Reynolds et al. 2003). Theoretical studies show that negative plant-soil feedback can contribute to the coexistence of competitive plant species that compete for the same soil and light resources (Bever et al. 1997, Bever 2003, Bonanomi et al. 2005). Empirical studies emphasize the potential role of plant-specific accumulation of soil-borne pathogens and negative feedbacks in species replacements (Van der Putten et al. 1993, Van der Putten and Peters 1997).

Plant-induced changes in the soil community have been shown to be responsible for reduced growth of early-successional species (Keever 1950, Van der Putten et al. 1993, Bever 1994). However, the role of such feedbacks in temporal plant community dynamics has received little attention (Bardgett et al. 2005, BarteltRyser et al. 2005, Kardol et al. 2006). So far it is unclear how plant-specific changes in soil communities contribute to plant community dynamics and the rate of successional replacements, as well as how long these effects remain operational (Van der Putten 2003). When plant-soil feedback reduces the competitive ability of an early-successional plant species, this may strongly affect the outcome of interspecific competition with later successional species (Bever 2003). However, the influence of an early-successional species on the soil community composition could also result in a biotic legacy effect that influences plant community dynamics and patterns of plant dominance in later successional stages.

One of the critical steps in understanding the process of succession is to analyze how plant-soil feedback may influence plant community interactions. We constructed microcosm ecosystems composed of plant species characteristic for early and midsecondary succession stages on ex-arable land. In order to provide all earlysuccessional plant species with the same competitive environment, and also to obtain a succession scenario that is realistic in field conditions, we used a mixture of four mid-successional plant species and analyzed how interspecific competition influenced plant-soil feedback effects. Initial plant communities on fertile, ex-arable land are dominated by arable weeds established from the seed bank and long-distance dispersed pioneer species. These species are characterized by fast growth rates (Chapin et al. 1994, Grime 2001), and the lowdiversity early-succession plant communities, often consisting of locally single species patches, may provide conditions that are typical for pathogens to flourish (Coley et al. 1985, Burdon 1987, Herms and Mattson 1992). Little is known about the relationship between plant successional type and feedback with the soil community (Jarosz and Davelos 1995, Reynolds et al. 2003, Van der Putten 2003).

In a greenhouse experiment using a two-phase feedback approach (Bever 1994), we tested first the hypothesis that in secondary succession, species-specific plant-induced changes in soil community composition reduce the competitive ability of early-successional species (Van der Putten and Peters 1997, De Deyn et al. 2003). Second, we tested the hypothesis that soil microorganisms are involved in these plant-soil feedbacks. This hypothesis was tested by isolating the microbial component of the soil community (Klironomos 2002, Bezemer et al. 2005) and re-inoculating the microorganisms into sterilized soil. We also studied the effects of the soil microorganisms on other early- and mid-successional plant species. The fungal and bacterial components of the rhizosphere community were characterized molecularly by denaturing gradient gel electrophoresis (DGGE) in order to detect plant speciesspecific changes in the dominant bacterial and fungal taxa present in the rhizosphere. Finally, we analyzed contingency effects of plant-soil feedback in earlysuccessional stages on plant community composition in mid-successional stages by comparing the performance of the mid-successional plant species in relation to the history of plant-soil feedback.

\section{Methods \\ Soil}

In February 2005, the soil for the experiment was obtained from the upper $15 \mathrm{~cm}$ of a maize (Zea mays L.) field in Renkum, The Netherlands $\left(52^{\circ} 00^{\prime} \mathrm{N}, 5^{\circ} 45^{\prime} \mathrm{E}\right)$. It was a coarse, loamy sand, neutral in $\mathrm{pH}$ and rich in available nitrogen and phosphorus (Appendix A), which 
is a usual start situation for secondary succession on exarable land (Van der Wal et al. 2006b). The soil was sieved using a $10-\mathrm{mm}$ mesh in order to remove stones and large organic particles, hand mixed, and stored in polypropylene bags outdoors (frost-free) until the experiment was set up. Before the start of the experiment, five subsamples from the soil were collected to determine soil moisture content after drying at $75^{\circ} \mathrm{C}$ for $48 \mathrm{~h}, \mathrm{NH}_{4}^{+}$and $\mathrm{NO}_{3}^{-}$using $\mathrm{KCl}$ extraction, available $\mathrm{P}$ using $\mathrm{CaCl}_{2}$ extraction, and $\mathrm{pH}$ in 1:2.5 dry soil: water suspensions.

\section{Plant species}

As early-successional plant species, we used three grasses, Alopecurus geniculatus L. (marsh foxtail), Apera spica-venti L. (loose silkybent), and Poa апnиa L. (annual bluegrass), and three forbs, Capsella bursapastoris L. (shepherd's purse), Conyza canadensis L. (Canadian horseweed), and Viola arvensis Murray (European field pansy). As mid-successional plant species, we used the grasses, Agrostis capillaris L. (common bent) and Anthoxanthum odoratum L. (sweet vernal grass), as well as two forbs, Achillea millefolium L. (common yarrow) and Plantago lanceolata L. (narrowleaf plantain). All species are typical for earlyand mid-successional stages of secondary succession after land abandonment on sandy or sandy loam glacial deposits in The Netherlands (Kardol et al. 2005).

\section{Seeds}

Plant seeds of $C$. canadensis and $A$. spica-venti were obtained from two ex-arable fields located in the same geographical region (Assel, 52 $21^{\prime} \mathrm{N}, 5^{\circ} 82^{\prime} \mathrm{E}$; Renkum, $52^{\circ} 00^{\prime} \mathrm{N}, 5^{\circ} 45^{\prime} \mathrm{E}$ ). Seeds of the other plant species were provided by specialized suppliers (Cruydt-hoeck, Groningen, The Netherlands; Rieger-Hofmann, BlaufeldenRaboldshausen, Germany). Seeds were sterilized with a $0.1 \%$ chloride solution for $3 \mathrm{~min}$ and sown on glass beads, moistened with demineralized water, and germinated in a cabinet of 16:8 h light: dark (L:D) photo regime and $22: 18^{\circ} \mathrm{C}$ temperature regime. One week after germination, seedlings were placed in a climate chamber at $4^{\circ} \mathrm{C}$ with light according to the L:D regime until transplanting to ensure that all species were of comparable ontogenetic state at the start of the experiment.

\section{Experiment 1 a}

In order to create different soil histories, we established microcosms with monocultures of each of the early-successional plant species to obtain "home soils" and with mixtures of the five remaining early-successional plant species to obtain "foreign soils." Each treatment was replicated five times. Experiment 1a was duplicated to allow us to test the treatment effects (home soil, foreign soil) in two competitive environments in experiment $1 \mathrm{~b}$. Hence the design of experiment $1 \mathrm{a}$ involved 6 species $\times 2$ designs (monocultures and mixtures) $\times 5$ replicates $\times 2$ duplicates, equal to 120 microcosms. The microcosms were containers of $18 \times$ $18 \times 18 \mathrm{~cm}^{3}$ filled with the field soil $(15 \% \mathrm{w}: \mathrm{w})$ planted with 25 seedlings of an early-successional species to create home soil, or 5 seedlings of each of the five remaining plant species (adding up to a total of 25 seedlings) to create foreign soil. Each of the replicates of the mixed plant communities had a randomly defined plant configuration to avoid positioning effects. Microcosms were randomly placed on trolleys in a greenhouse. The light regime was minimally $16 \mathrm{~h} / \mathrm{d}$ of light, and natural daylight was supplemented with metal halide lamps $\left(225 \mu \mathrm{mol} \cdot \mathrm{s}^{-1} \cdot \mathrm{m}^{-2}\right.$ photosynthetically active radiation) to ensure minimum light supply and a L:D temperature regime of $21: 16^{\circ} \mathrm{C}$. The positions of the trolleys were shifted three times a week to minimize effects of microclimate differences within the greenhouse. In the first week of the experiment, plants that died were replaced. Plants were watered daily with demineralized water, and twice a week initial soil moisture level was reset by weighing. After two months, plants were harvested by clipping the shoots at the soil surface. Shoot dry mass of each microcosm was determined after drying at $70^{\circ} \mathrm{C}$ for minimally $72 \mathrm{~h}$, and shoots of the mixed plant communities were sorted, dried, and weighed to species. After harvest, the soil of each separate microcosm was homogenized while removing node-bearing plant fragments and rhizomes to prevent regrowth. The roots were left in the soil so as to preserve the microbial communities that had been developed in the rhizosphere.

\section{Experiment $1 b$}

In order to determine the soil feedback effect on the six early-successional plant species, seedlings of each species were planted in their home and foreign soil originating from experiment 1a. For each of the six early-successional species, feedback effects were tested in two competitive environments: (1) in monocultures, and (2) in mixed communities with heterospecifics (Fig. 1). Monocultures were composed of 25 seedlings of an early-successional species. Mixed communities were composed of 5 seedlings of an early-successional species plus 5 seedlings each of four mid-successional plant species. Fig. 1 shows a diagram of the experimental setup for Pоа аппиа. The experimental design involved 6 early-successional plant species $\times 2$ soil histories (home and foreign) $\times 2$ competitive environments (monocultures providing intraspecific competition and mixed communities with heterospecifics providing interspecific competition) $\times 5$ replicates, equal to 120 microcosms. Each of the replicates of the mixed plant communities had a randomly defined plant configuration to avoid positioning effects. Three weeks after establishing the experiment, in each microcosm the shoot length of 5 early-successional individuals was measured. In the monocultures of each replicate, we selected the individuals at positions that corresponded with the positions of their conspecifics in the mixed community of that 

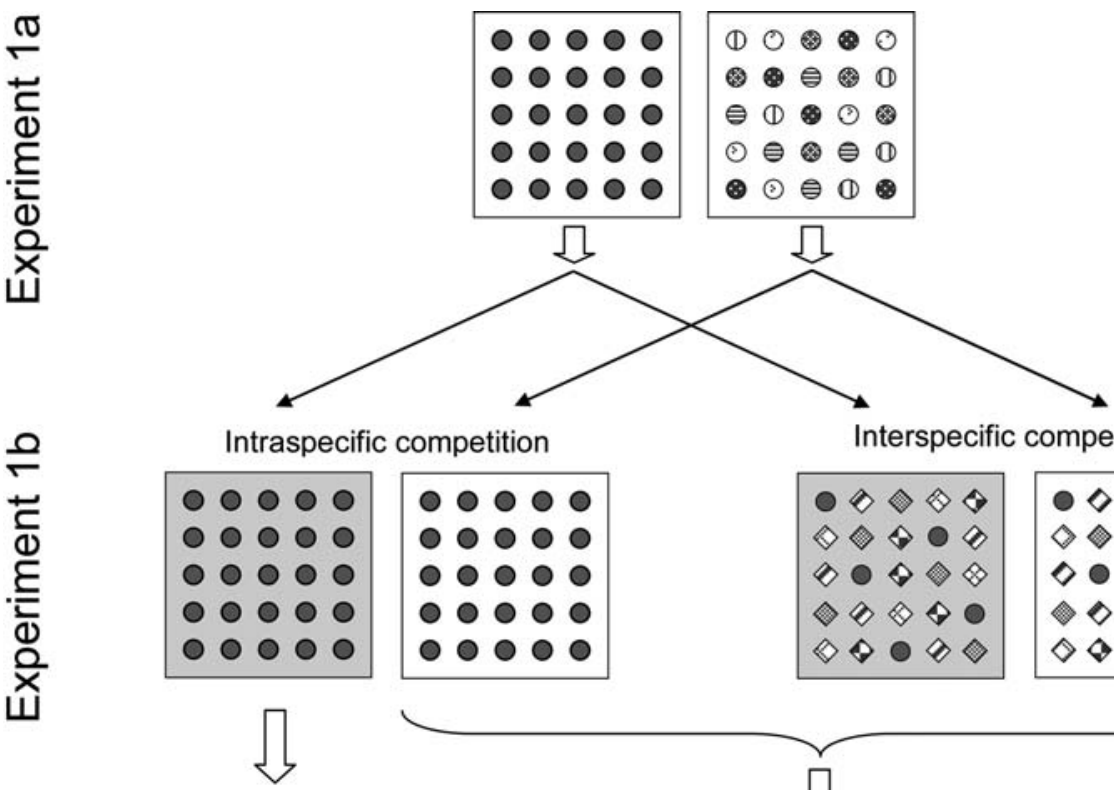

After harvest, soil used for microbial inoculum (experiment 2)

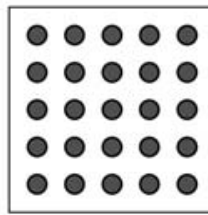

Interspecific competition

After harvest, soils aggregated, homogenized, and sterilized (experiment 2)

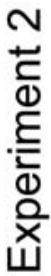

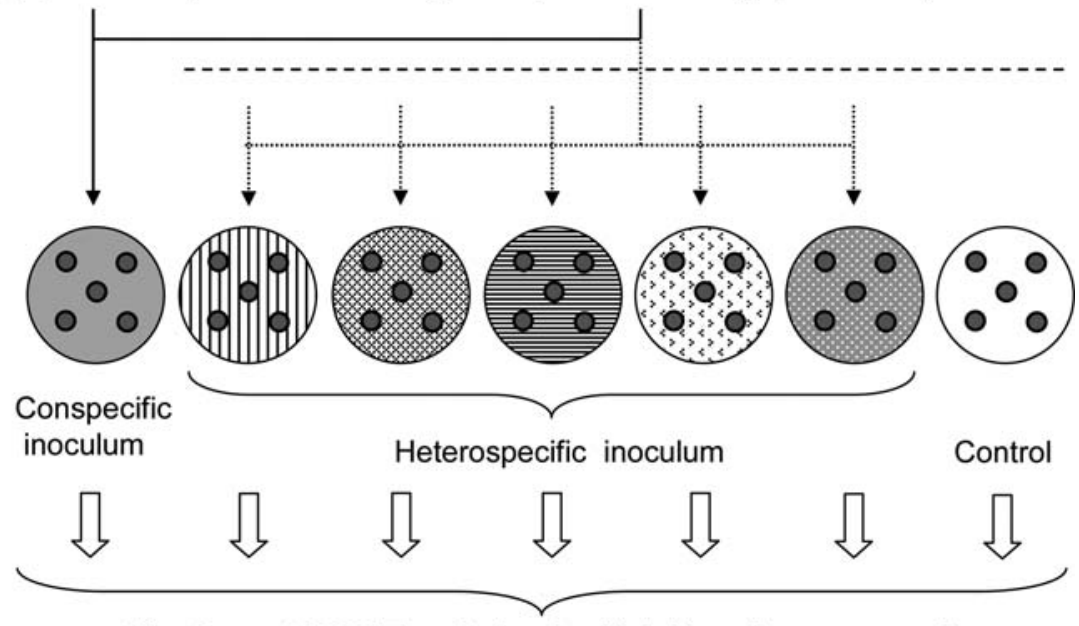

After harvest, DGGE analysis microbial rhizosphere community

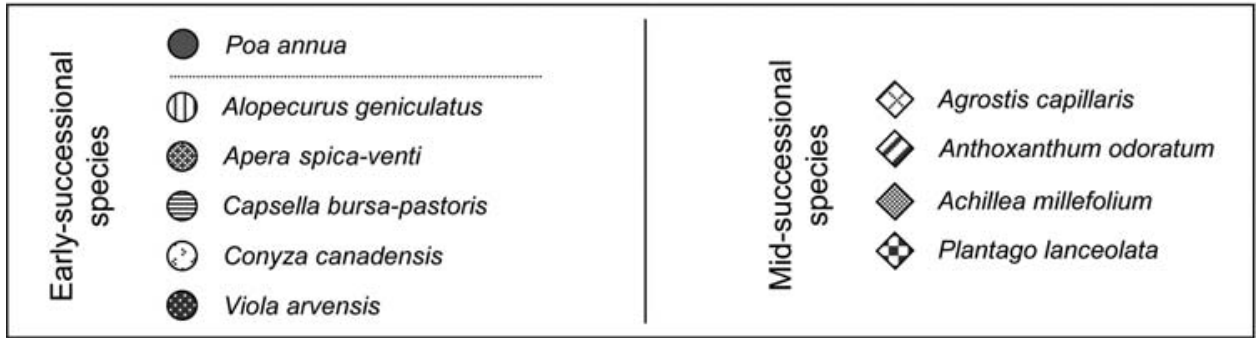

FIG. 1. Example of the full experimental design for one of the early-successional plant species, Poa annua. Shown are diagrammatic microcosms of a single replicate. Denaturing gradient gel electrophoresis analyses (DGGE) were not performed for the other plant species. 
replicate. Plants were grown for two months and harvested as in experiment 1a.

\section{Experiment 2}

In order to single out the contribution of the microbial soil community to the observed plant-soil feedback patterns in experiment $1 \mathrm{~b}$, we collected the soil microorganisms from the monocultures on home soils of each early-successional plant species. The experimental design involved 10 species (6 early-successional species and 4 mid-successional species) $\times 7$ treatments $(6$ earlysuccessional inocula and 1 control treatment) $\times 5$ replicates, equal to 350 pots. Microbial inocula of each early-successional plant species were made by adding $15 \mathrm{~L}$ of tap water to $15 \mathrm{~kg}$ of home treatment soil (Bezemer et al. 2005). These mixtures were left for $5 \mathrm{~h}$ to enable large particles to sink, after which the supernatant was sieved through a $75-\mu \mathrm{m}$ mesh, followed by two sieves of $45 \mu \mathrm{m}$ and two sieves of $30 \mu \mathrm{m}$. This method omitted the micro-arthropods and nematodes, as well as mycorrhizal fungi (Ames et al. 1987) but let most other microorganisms in the suspension pass through.

Soils on which either in the first or the second stage of experiment 1 mixed communities had been grown (Fig. 1) were aggregated, and node-bearing plant fragments and rhizomes were removed. The aggregated soil was homogenized, sterilized by $\gamma$-irradiation $(25$ $\mathrm{kGy}$ ), and a subsample was analyzed for nutrients (Appendix B). Pots $11 \mathrm{~cm}$ high with bore diameter 9$13 \mathrm{~cm}$ (basis to top) were filled with $900 \mathrm{~g}$ of sterilized soil, and monocultures of all early- and mid-successional species were established ( 5 seedlings per pot; see Plate 1, upper left). At the second, third, and fourth day after planting, the pots were injected with a total of $145 \mathrm{~mL}$ microbial inoculum originating from soil of one of the six early-successional species or, as a control, $145 \mathrm{~mL}$ of tap water. Plants were grown as in experiment 1. After two months, the plants were harvested by clipping the shoots at the soil surface, and roots were washed from the soil. Shoot and root dry mass were determined after drying at $70^{\circ} \mathrm{C}$ for minimally $72 \mathrm{~h}$. Soil chemical analyses were made for the original six soil batches (Appendix C), as well as for the soil inocula (Appendix B). We analyzed $\mathrm{NH} 4+, \mathrm{NO}_{3}{ }^{-}$, available $\mathrm{P}, \mathrm{K}$, and $\mathrm{Mg}$. Microbial inocula were checked for the presence of nematodes, which were not found.

We analyzed the molecular community profiles of the soil microorganisms in the inocula, as well as in the rhizosphere soil of Poa annua plants in experiment 2, as this early-successional species showed strong feedback and inoculum effects. We used a culture-independent molecular approach, involving direct DNA isolation, polymerase chain reaction (PCR) of fungal 18S rRNA and bacterial $16 \mathrm{~S}$ rRNA genes, and denaturing gradient gel electrophoresis (DGGE) (Muyzer et al. 1993, Kowalchuk and Smit 2004). After the harvest of experiment 2, pieces of young roots of $P$. annua with the remaining adhering soil were collected for all treatments. The roots were chopped into $1-\mathrm{cm}$ pieces and homogenized in order to obtain rhizosphere samples. DNA was extracted from 0.25 -g subsamples of $P$. annua rhizosphere, as well as from $0.25-\mathrm{mL}$ subsamples of the microbial inocula, using a Power Soil Kit (Mo BIO Laboratories, Carlsbad, California, USA), and used for PCR. Fragments of bacterial $16 \mathrm{~S}$ ribosomal DNA were amplified with the primers 968CG and 1378r (Heuer et al. 1997, 1999). Fragments of fungal $18 \mathrm{~S}$ ribosomal DNA were amplified with the primers Fr1GC and FF390 (Vainio and Hantula 2000). For bacterial DNA we used the Acter 5535 program, and for fungal DNA the fun47-40 touch-down cycling program (both programs from PTC-200, MJ Research, Biorad Veenendaal, The Netherlands, Appendix D). Amplification reactions were performed in a volume of $25 \mu \mathrm{L}$ and consisted of $15 \mathrm{nmol} / \mathrm{L}$ of each primer, approximately $50 \mathrm{ng}$ of environmental template DNA, 1 U Expand High Fidelity DNA polymerase (Boehringer, Mannheim, Germany), and the manufacturer's recommended nucleotide concentrations and buffer conditions. PCR products were used for DGGE analysis, using the methods of Muyzer et al. (1993) for bacterial products and the method of Kowalchuk and Smit (2004) for fungal products. Linear gradients from $45 \%$ to $65 \%$ and from $40 \%$ to $55 \%$ denaturant were used for bacterial and fungal products, respectively.

\section{Data analysis}

Plant-soil feedback of the early-successional plant species was calculated as $100\left(B_{\mathrm{h}}-B_{\mathrm{f}}\right) /\left(B_{\mathrm{f}}\right)$, where $B_{\mathrm{h}}$ is shoot biomass in an individual replicate home soil, and $B_{\mathrm{f}}$ is the mean shoot biomass of all five replicates in foreign soil of that particular early-successional plant species. Feedback responses were calculated using data of experiment $1 \mathrm{~b}$, both for monocultures and for earlysuccessional plant species in the mixed plant communities. The same formula was used to calculate feedback effects after three weeks of experiment $1 \mathrm{~b}$, substituting plant length for biomass. Feedback responses were analyzed using maximum likelihood estimation (type III, PROC MIXED, SAS Institute, Cary, North Carolina, USA) with design (monoculture or heterospecific competition), plant guild (grass or forb), and design $\times$ plant guild as fixed factors, and plant species nested within plant guild and design $\times$ species(plant guild) as random factors. Because the variance components of the random effects were not significant, only effects of fixed factors are reported and discussed. The measures of feedback response met the parametric assumption of normality (KolmogorovSmirnov tests, $P>0.05)$. The assumption of homogeneity of variances was met at the $P>0.01$ level (Cochran's, Hartley's, and Bartlett's tests). In separate analyses, for each plant species, differences in feedback responses between monocultures and mixed plant communities were analyzed using a one-way general linear model (GLM) with design as fixed factor. If 

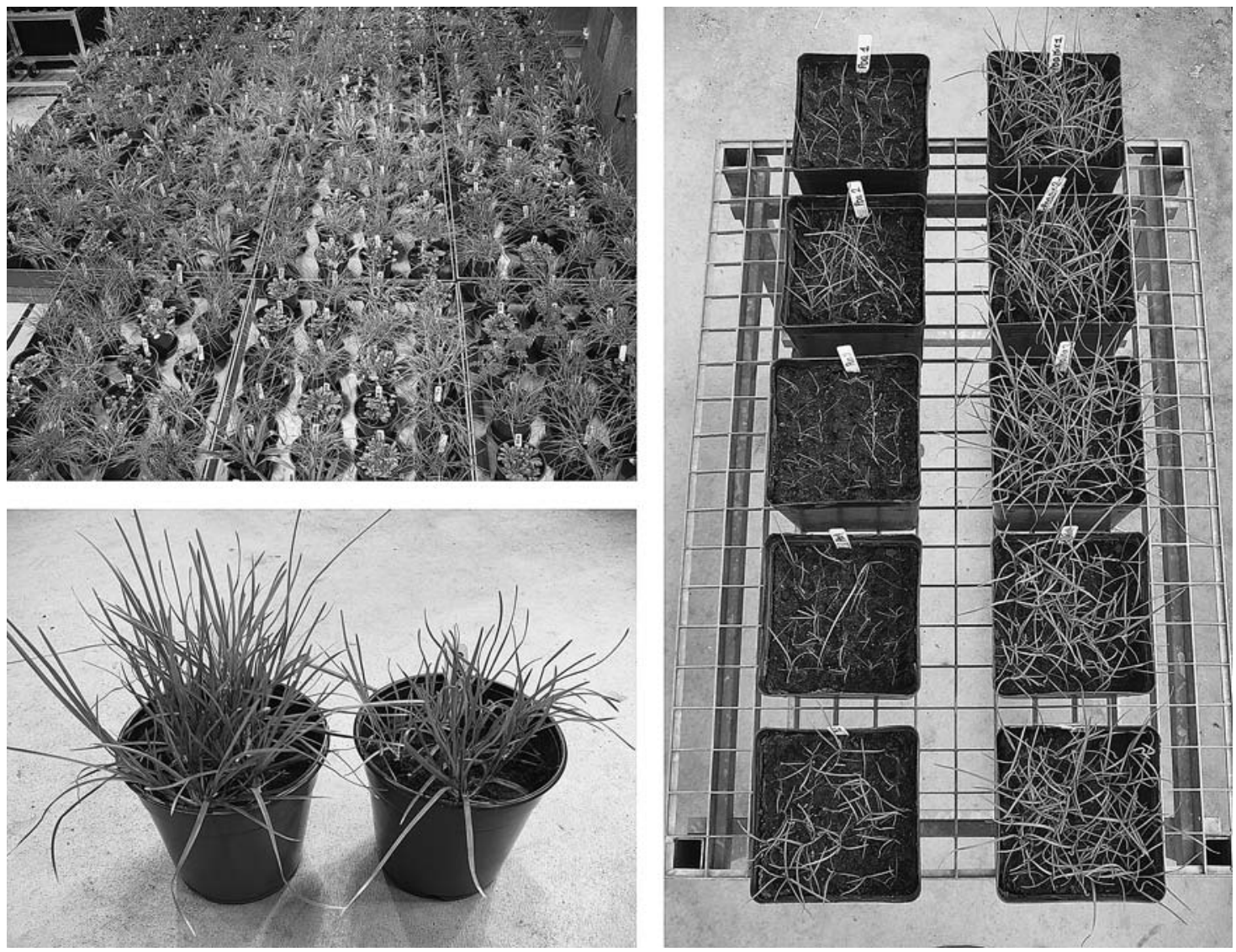

Plate 1. (Upper left) Monocultures of early- and mid-successional plant species grown on sterilized soil injected with microbial inoculum from conspecific or heterospecific origin (experiment 2). (Lower left) Monocultures of Poa annua grown on sterilized soil injected with microbial inoculum from conspecific (right) or heterospecific (left) origin (experiment 2). (Right) Monocultures of Poa annua grown on soil from conspecific (left) and heterospecific origin (experiment 1b), indicating negative plant-soil feedback. Photo credits: P. Kardol.

feedback responses differed from zero, $t$ tests were used. To rule out that feedback responses may have been affected by differences in biomass production between home and foreign soil treatments in the first stage of the experiment (Appendix E), the difference in biomass production between home and foreign treatments in experiment 1a was used as a covariate in the PROC MIXED model. Further, we used linear regression to check for relationships between shoot biomass in the first and the second stage of the experiment. Principal components analysis (PCA) and redundancy analysis (RDA) (499 unrestricted permutations; CANOCO, Version 4.5, Ter Braak and Šmilauer 1998-2002) were used to test contingency effects as a result of the different early-successional plant species that had been grown on the soils in the first stage of the experiment. We analyzed the effects of soil histories caused by the early-successional plant species on the composition of mid-successional plant species in the second stage of the experiment. Because the identity of the competing earlysuccessional species changed in unison with the treatments (i.e., the soil history), RDA was carried out both with and without adding shoot biomass of the competing early-successional species as covariate. Similarly, we tested the effect of total shoot biomass production in the first or second stage of the experiment. For PCA and RDA, biomass data for each individual microcosm were used.

For each plant species, effects of microbial inocula (experiment 2) were calculated as inoculum effect $=100\left(B_{\mathrm{i}}\right.$ $\left.-B_{\mathrm{c}}\right) /\left(B_{\mathrm{c}}\right)$, where $B_{\mathrm{i}}$ is total root + shoot biomass of each replicate with microbial inoculum added, and $B_{\mathrm{c}}$ is mean total root + shoot biomass of the five replicate sterilized controls. For early-successional plant species, inocula effects were analyzed using maximum likelihood estimation (type III, PROC MIXED, SAS Institute) with inoculum species (i.e., the early-successional plant species from which the inoculum originated) as fixed factor, and plant species and plant species $X$ inoculum species as random factors. Contrasts between inocula from conspecific and heterospecific origin were tested within the observed levels of the random effect (narrow inference space), i.e., within the species levels. For mid-successional plant species, inocula effects were analyzed utilizing two 


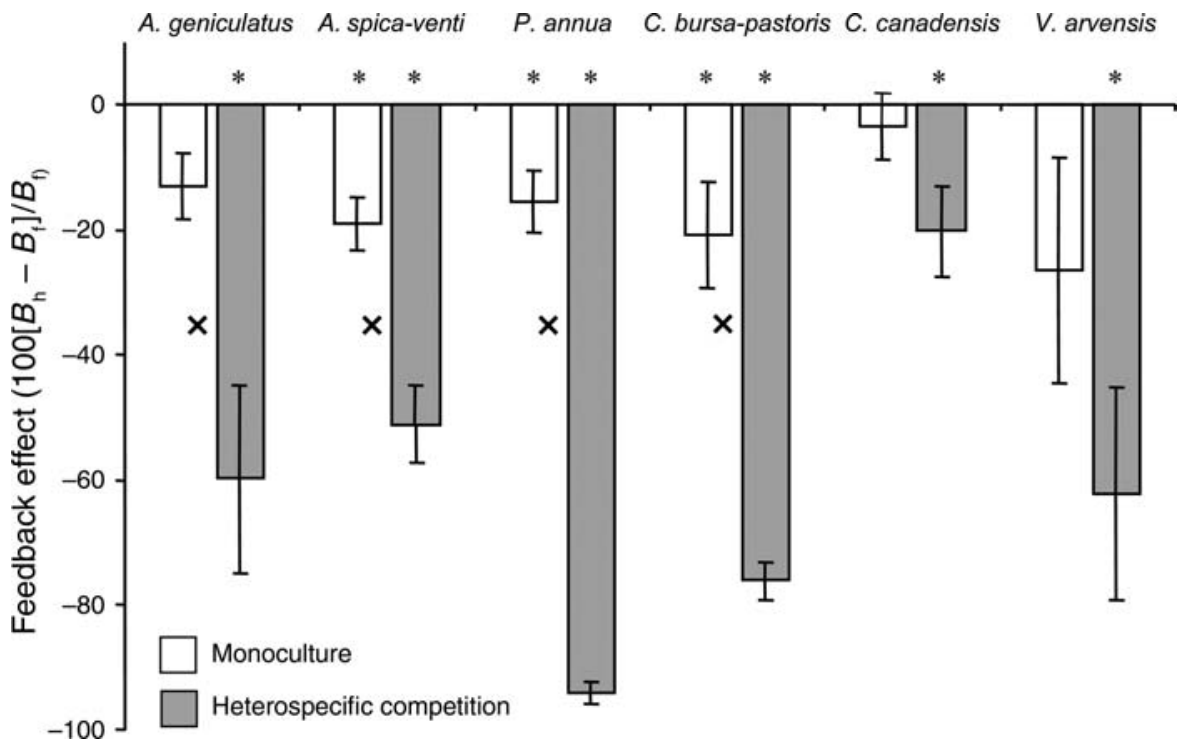

FIG. 2. Change in shoot biomass production (mean $\pm \mathrm{SE}$ ) of early-successional plant species when grown in soil previously colonized by conspecifics (home soil) as compared to soil in which heterospecifics have been growing (foreign soil). Open bars indicate feedback effects in monocultures, and gray bars indicate feedback effects of the early-successional species in mixed communities with mid-successional species (e.g., with heterospecific competition). $B_{\mathrm{h}}$ is biomass in home soil, and $B_{\mathrm{f}}$ is mean biomass in foreign soil. Asterisks indicate feedback effects significantly different from zero $(t$ tests, $P<0.05)$; X symbols indicate a significant difference (one-way ANOVA, Mann-Whitney $U$ test, $P<0.05$ ) between feedback effects in monocultures and in mixed communities. Scale numbers on the $y$-axis represent the reduction effect measured as percentage change in biomass.

distinctive procedures. First, we used a GLM with plant guild (grass or forb), inoculum guild (originating from early-successional grass or early-successional forb), plant species nested within plant guild, and inoculum species nested within inoculum guild as fixed factors. The following interactions were included: plant guild $\times$ inoculum guild, plant guild $\times$ inoculum species(inoculum guild), and inoculum guild $\times$ plant species(plant guild). Second, we used maximum likelihood estimation (type III, PROC MIXED, SAS Institute) with plant guild, inoculum guild and their interaction as fixed factors, and plant species nested within plant guild and inoculum guild $\times$ plant species(plant guild) as random factors. In separate analyses, for each plant species, statistical differences between inocula were analyzed using Tukey's hsd post hoc tests after one-way GLM, with inoculum origin as fixed factor. The measures of inoculum effects met the parametric assumptions of normality (KolmogorovSmirnov tests, $P>0.05$ ) and homogeneity of variances (Cochran's, Hartley's, and Bartlett's tests, $P>0.05$ ). For each plant species, inocula effects were tested to differ from zero with Bonferroni-adjusted $t$ tests.

Bacterial and fungal DGGE gels were read into the ImageMaster Elite program (Version 4.20, Amersham Pharmacia Biotech, Piscataway, New Jersey, USA). Matching of bands was performed in reference to a hypothetical composite lane containing bands at all positions found across the entire dataset. Comparisons of bacterial and fungal DGGE profiles used Pearson's similarity indices for each pairwise lane comparison, taking both band number and intensity into account after background subtraction and signal normalization using the ImageMaster Elite Database program (Version 2.0, Amersham Pharmacia Biotech, Piscataway, New Jersey, USA). PCA was carried out on bacterial and fungal DGGE profiles. Effects of inoculum origin on bacterial and fungal rhizosphere community composition were tested in RDA with Monte Carlo permutation tests. The relationship between microbial rhizosphere community composition and biomass production of P. аппиа (root, shoot, and total) was determined by linear regression analysis using the first and second axis sample scores derived from PCA carried out on bacterial and fungal DGGE profiles.

\section{Results \\ Feedback effects (experiment 1)}

Plant-soil feedback responses of the early-successional species were generally negative (see Plate 1 , right) and significantly increased when the plants were grown in a competition with heterospecifics (design: $F_{1,4}=25.80, P$ $<0.007$; Fig. 2). Over all plant species, plant-soil feedback reduced biomass production by $16.8 \%$ in monocultures and by $67.1 \%$ when grown with heterospecific competition. Individual species differed somewhat in their responses. Three of the six earlysuccessional plant species experienced a negative feedback ( $t$ tests, $P<0.05$; Appendix F) from their soil community when plants were grown in monocultures (Fig. 2). For Alopecurus geniculatus, Conyza canadensis, and Viola arvensis, the feedback response in monocultures did not differ significantly from zero $(t$ tests, $P>$ 


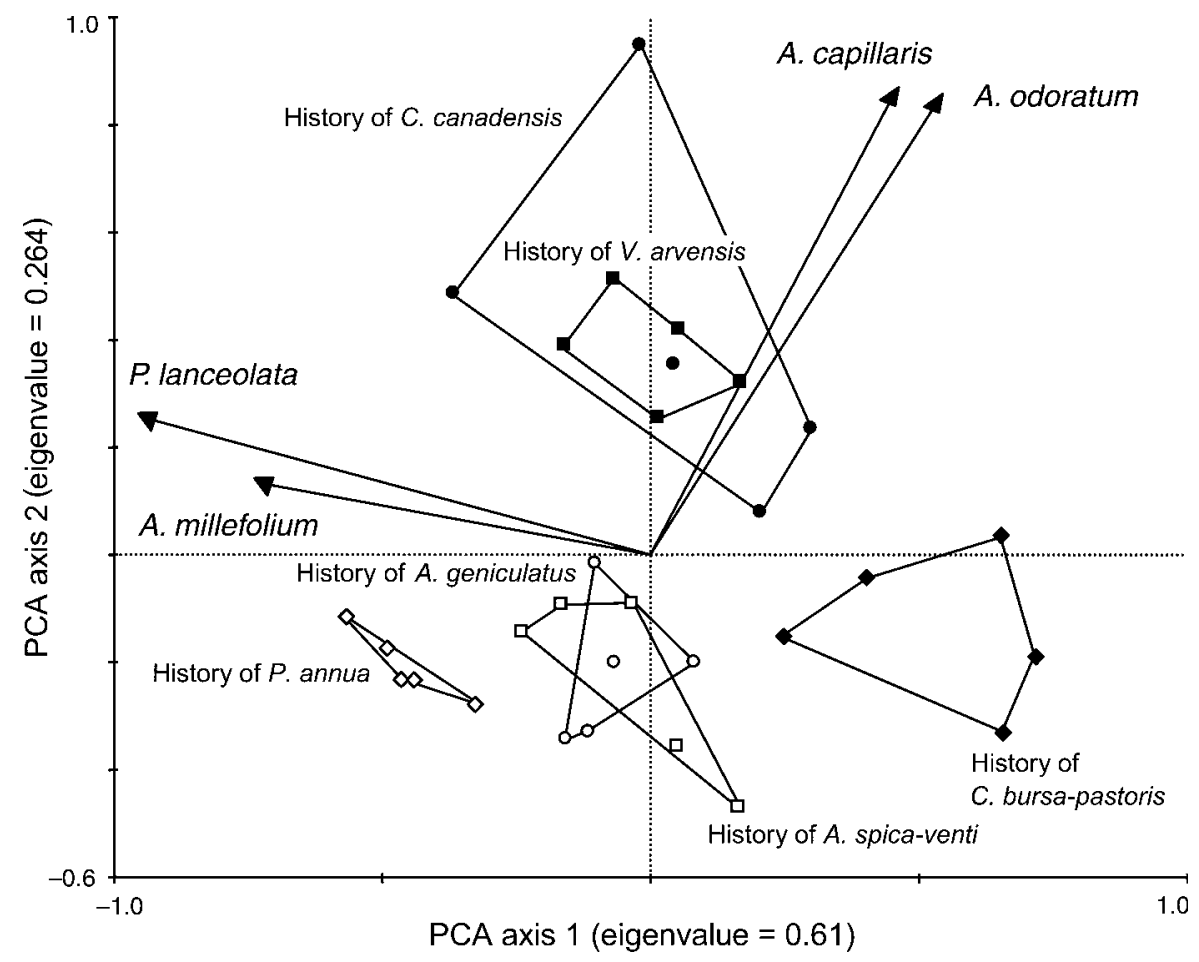

FIG. 3. Ordination diagram (species-samples biplot) of principal components analysis for mid-successional plant species (grasses Agrostis capillaris and Anthoxanthum odoratum; forbs Plantago lanceolata and Achillea millefolium) grown in soil with histories of early-successional plant species. Each data point represents one microcosm. Open symbols represent soils with histories of grasses (circles, Alopecurus geniculatus; squares, Apera spica-venti; diamonds, Poa annua) and solid symbols represent soils with histories of forbs (circles, Conyza canadensis; squares, Capsella bursa-pastoris; diamonds, Viola arvensis). Envelopes are drawn around samples with replicate soil histories. Eigenvalues along the axes indicate the amount of explained variability in species composition.

0.05; Appendix F). When grown in competition with heterospecifics, all early-successional species experienced a negative feedback ( $t$ tests, $P<0.05$; Appendix F) from their soil community. For A. geniculatus, Apera spicaventi, Poa annua, and Capsella bursa-pastoris, the soil feedback was significantly more negative when they were grown in a competitive environment than when grown as monospecific stands (Fig. 2, Appendix G). Forbs and grasses did not differ in their feedback responses (plant guild: $F_{1,4}=0.26, P=0.64$ ), and there was no design $\times$ plant guild interaction $\left(F_{1,4}=1.00, P=0.37\right)$.

After the first three weeks of growth, the negative feedback effects were already detectable, and these effects were independent of heterospecific competition (data not shown). For all treatments, total shoot biomass per microcosm was higher in the first stage of experiment 1 than in the second stage (Appendix E). There was no relationship between shoot biomass in the first and the second stage of the experiment for any of the plant species (for all microcosms $R^{2}=4.0 \times 10^{-5}, P=$ $0.94)$, which reduces the likelihood that the observed feedback effects were due to nutrient depletion. Moreover, adding the difference in biomass production between home and foreign treatments in the first stage of the experiment (Appendix E) as a covariate to the
GLM model did not qualitatively affect our results (data not shown). Therefore the observed plant-soil feedback effects appeared to be strongly due to interactions of the plants with pathogenic or root-feeding rhizosphere organisms.

Moreover, results from the feedback experiment showed that the history of early-successional plant species effects on soil community development in the first stage of the feedback experiment influenced the performance of the mid-successional plant species in the mixed communities (Fig. 3). Although no species were consistently lost with respect to soil history (data not shown), principal components analysis (PCA) revealed clear clustering of samples of mid-successional plant species, based on the early-successional species that had previously been grown on the soils (Fig. 3). The first and second PCA axis explained, respectively, $61 \%$ and $26 \%$ of the variation in composition (i.e., biomass distribution) of the mid-successional species. The mid-successional grasses Agrostis capillaris and Anthoxanthum odoratum performed less well on soils with a history of early-successional grasses, indicated by their negative correlations to soils originating from early-successional grasses and positive correlations to soils originating from early-successional forbs (Appendix H). Redun- 
dancy analysis (RDA) showed that the contingency effect of soil history on mid-successional plant composition was highly significant $(F=23.19, P=0.002)$. These shifts in community composition could not be fully described to differences in total biomass production. Adding total shoot biomass in the first or the second stage of the experiment (Appendix E) as covariates in RDA resulted in a reduction in the sum of all canonical eigenvalues from 0.718 to 0.661 and 0.497 , respectively. Adding the shoot biomass production of the competitive early-successional species in the second stage of the experiment (Appendix E) resulted in a sum of all canonical eigenvalues of 0.602 . When using one or combinations of these covariates, soil history still explained a highly significant amount of the variation $(P=0.002)$, indicating legacy effects of changes in soil biological properties as affected by the early-successional species influencing the dynamics of mid-successional plant communities. In contrast to the effects of monoculture soils, the soils of the mixed communities of early-successional plant species (e.g., foreign treatments) did not reveal any distinct clustering in PCA, and RDA did not show a significant effect of soil history (data not shown).

\section{Inoculum effects (experiment 2)}

Inoculum effects for early-successional plant species were generally neutral to strongly negative (Fig. 4, Appendix I), and the plants were affected by microbial inocula from conspecific origin more than by inocula from heterospecific origin (Fig. 4, Table 1). Irrespective of conspecificity and heterospecificity, inocula effects could not be attributed to the specific origin nor was the variance component of the random plant species effect significant (Table 1). However, the variance component of the random plant species $\times$ inoculum species interaction was highly significant (Table 1). Therefore, comparisons between conspecific and heterospecific inoculum origin were tested within plant species (see Plate 1, lower left). The complementary contrast analyses showed that five of the six species were more strongly affected by inocula from conspecific origin than by inocula from heterospecific origin (Table 1). For example, the microbial inoculum from conspecific origin reduced biomass of A. geniculatus by about $60 \%$ compared to the control without inoculum, whereas the microbial inocula from the other plant species (heterospecific origin) reduced biomass of $A$. geniculatus no more than $30-40 \%$. The microbial inoculum of $V$. arvensis caused a $65 \%$ conspecific reduction in biomass production, whereas the heterospecific inocula did not affect plant biomass. In contrast to all other plant species, heterospecific microbial inocula positively influenced biomass production of Capsella bursa-pastoris, while the conspecific inoculum had a neutral effect (Fig. 4, Appendix I). The nonnative forb Conyza canadensis did not differ in its response to inocula from conspecific or heterospecific origin.
Effects of microbial inocula originating from earlysuccessional plant species on the performance of midsuccessional plant species differed strongly between grasses and forbs (GLM, plant guild: $F_{1,15}=117.13$, $P<0.0001)$, although there was also interspecies variation within plant guilds (GLM, plant species[plant guild]: $\left.F_{2,15}=12.40, P<0.0001\right)$. Furthermore, irrespective of the species origin (GLM, inoculum species[inoculum guild]: $F_{4,15}=0.25, P=0.91$ ), inocula from early-successional grasses showed stronger effects than inocula from early-successional forbs (inoculum guild: $\left.F_{1,15}=29.54, P<0.001\right)$. However, grasses and forbs differed in their responses to inoculum guild. Supporting the results from the feedback experiment (Fig. 3, Appendix H), biomass production of the midsuccessional grasses Agrostis capillaris and Anthoxanthum odoratum was reduced significantly more by inocula from early-successional grasses than from early-successional forbs (Fig. 5). In contrast, the midsuccessional forbs Achillea millefolium and P. lanceolata were far less influenced by the microbial inocula, and they did not respond differently to the inocula from early-successional grasses and forbs (Fig. 5), as indicated by the significant interaction between plant guild and inoculum guild (GLM, $F_{1,15}=5.81, P=0.0177$ ). The nested interaction terms plant guild $\times$ inoculum species(inoculum guild) and inoculum guild $\times$ plant species(plant guild) were not significant (GLM: $F_{4,15}=$ $0.42, P=0.79$ and $F_{2,15}=2.44, P=0.09$, respectively). Although the results indicate that the early-successional species provide species-specific soil legacies to which the mid-successional species respond differently, some prudence with respect to generalization may be appropriate. Actually, the PROC MIXED procedure, including plant species nested within plant guild as a random factor, revealed only marginally significant effects of plant species and inoculum species on the inoculum effect of mid-successional plant species, whereas the interaction between plant guild and inoculum guild was not significant (Appendix J).

\section{$D G G E$ analysis}

Similarity in microbial composition between inoculum samples and the respective rhizosphere samples was low (Pearson's index $=0.59 \pm 0.04$ [values reported as mean $\pm \mathrm{SD}]$ for fungal profiles and $0.49 \pm 0.03$ for bacterial profiles), indicating at shifts in dominant species in the microbial communities since the start of the experiment. DGGE on PCR products of amplified microbial rRNA from the inoculum samples produced 3 to 7 detectable bands for fungi and 7 to 14 bands for bacteria. Similarity between inoculum samples was significantly higher for bacteria than for fungi (Pearson's index $=0.96$ \pm 0.02 and $0.80 \pm 0.15$, respectively; Mann-Whitney $U$ test, $Z=-3.96, P<0.01)$. DGGE profiles for $P$. аппиа rhizosphere samples contained 3 to 13 fungal bands and 2 to 17 bacterial bands. PCA of bacterial and fungal rhizosphere patterns revealed high within-treatment 
Grasses
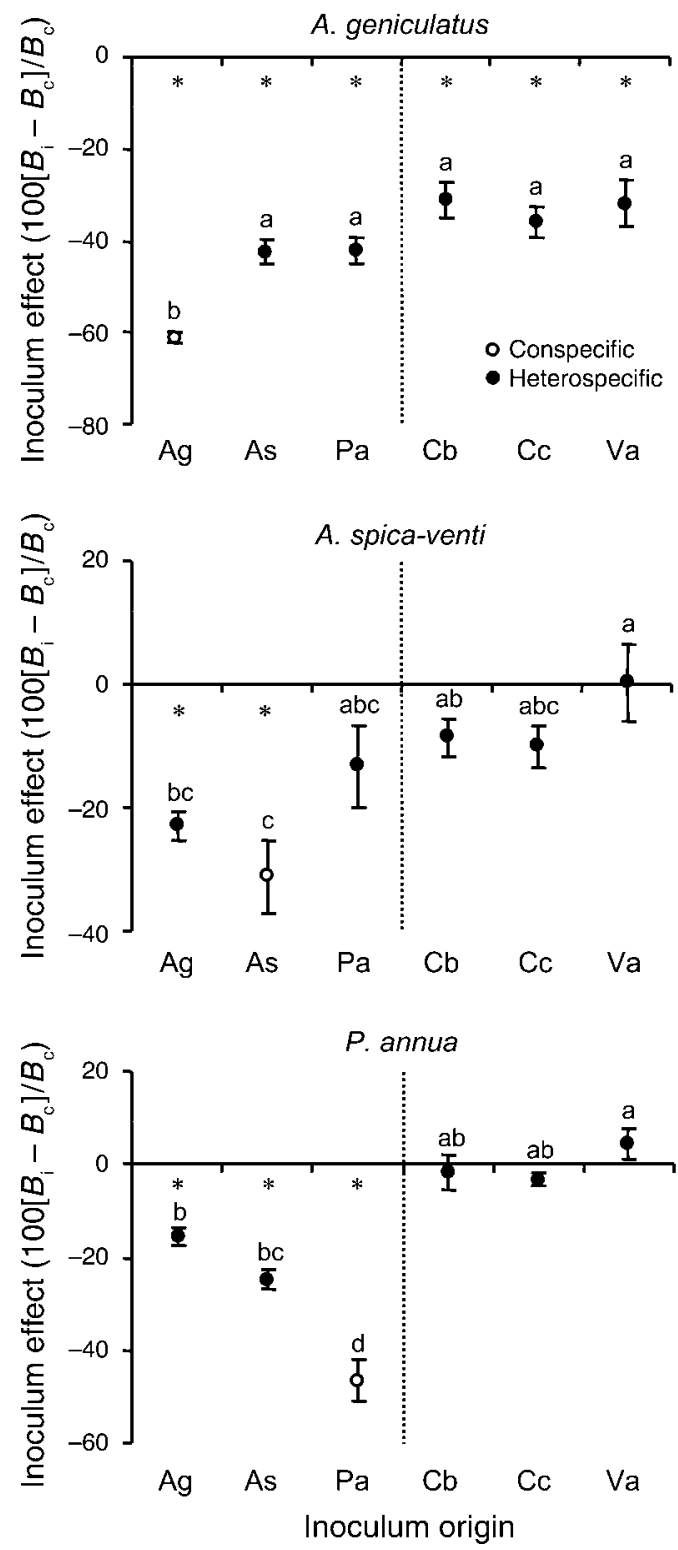

Forbs

C. bursa-pastoris

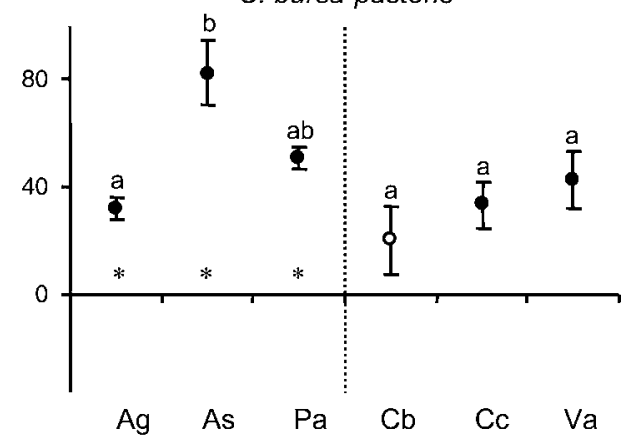

C. canadensis

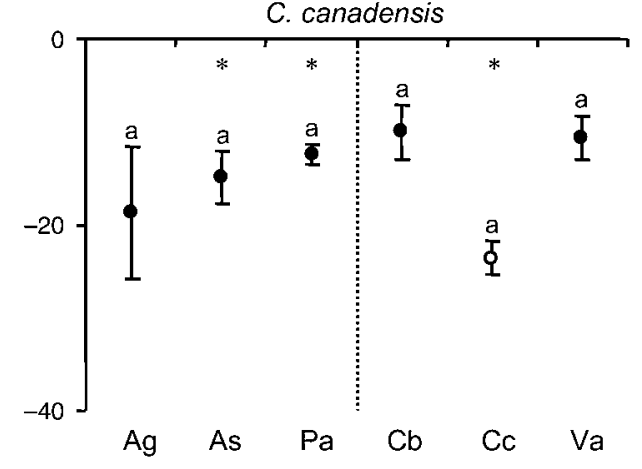

V. arvensis

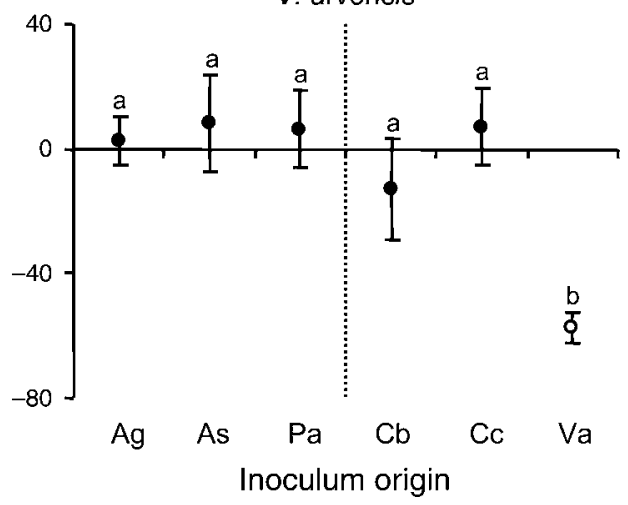

FIG. 4. Biomass production (mean $\pm \mathrm{SE}$ ) of early-successional grasses (left-hand panels) and forbs (right-hand panels) in soil with microbial inocula added $\left(B_{\mathrm{i}}\right)$ relative to soil without these inocula $\left(B_{\mathrm{c}}\right.$, biomass in sterilized control). The inocula originated from soils with histories of conspecifics (open symbols) and heterospecifics (solid symbols), as indicated by first letters of genus and species names (Ag, Alopecurus geniculatus; As, Apera spica-venti; Pa, Poa annua; Cb, Capsella bursa-pastoris; Cc, Conyza canadensis; Va, Viola arvensis). Asterisks indicate an inoculum effect significantly different from zero (Bonferroni-adjusted $t$ tests, $P$ $<0.05$ ). Different lowercase letters denote significant differences between means (one-way ANOVA, Tukey post hoc tests, $P<$ 0.05). Dotted vertical lines divide between inocula originating from grasses ( $\mathrm{Ag}, \mathrm{As}, \mathrm{Pa})$ and forbs $(\mathrm{Cb}, \mathrm{Cc}, \mathrm{Va})$. Scale numbers on the $y$-axis represent the reduction effect measured as percentage change in biomass.

variation (Appendix $\mathrm{K}$ ). The bacterial profiles did not reveal any clustering of samples, and strongest variation was observed in the control samples. Inoculum origin explained $17.9 \%$ of the variation in bacterial rhizosphere profiles, but this was not significant (RDA, MonteCarlo permutation tests for all canonical axes, $F$ ratio $=$ $1.018, P=0.41)$. PCA on fungal profiles showed weak clustering of the control samples; however, inoculum samples could not be distinctly separated from each other (Appendix K). Inoculum origin explained 20.7\% of the variation in fungal rhizosphere profiles, which was not significant (RDA, Monte-Carlo permutation tests for all canonical axes, $F$ ratio $=1.220, P=0.15$ ).

PCA clustering revealed a significant relationship between fungal rhizosphere community DGGE and total biomass production of $P$. аппи 
TABLE 1. Results from PROC MIXED analysis of effects of inoculum origin on plant biomass production relative to the sterilized control treatment (i.e., inoculum effect).

\begin{tabular}{lccrr}
\hline \hline \multicolumn{1}{c}{ Effect } & df & $F$ & $Z$ & \multicolumn{1}{c}{$P$} \\
\hline Inoculum species & 5,25 & 0.21 & & 0.9538 \\
Plant species & & & 1.47 & 0.0714 \\
Plant species $\times$ inoculum species & & & 3.03 & $<0.0001$ \\
Conspecific-heterospecific origin contrasts & & & & \\
$\quad$ Alopecurus geniculatus & 1,25 & 10.04 & & 0.0040 \\
Apera spica-venti & 1,25 & 5.89 & & 0.0228 \\
Poa annua & 1,25 & 23.39 & & $<0.0001$ \\
Capsella bursa-pastoris & 1,25 & 11.56 & & 0.0023 \\
Conyza canadensis & 1,25 & 1.39 & & $<0.2487$ \\
Viola arvensis & 1,25 & 55.52 & & $<0.0001$ \\
Overall & 6,25 & 18.31 & & $<0001$ \\
\end{tabular}

Notes: Inoculum species was included as a fixed factor in the model, and plant species and plant species $\times$ inoculum species were random factors. Contrasts between inocula from conspecific and heterospecific origin were tested within the observed levels of the random plant species effect.

(Table 2). This indicates that the observed microbial inocula effects can be due to changes in the presence or abundance of dominant fungal species in the rhizosphere. However, the relationship between shoot biomass and PCA sample scores from both the first and the second axes was significant, while this was not the case for root biomass. There was no relationship between bacterial rhizosphere community DGGE clustering and biomass production of $P$. annua (Table 2).

\section{Grasses}

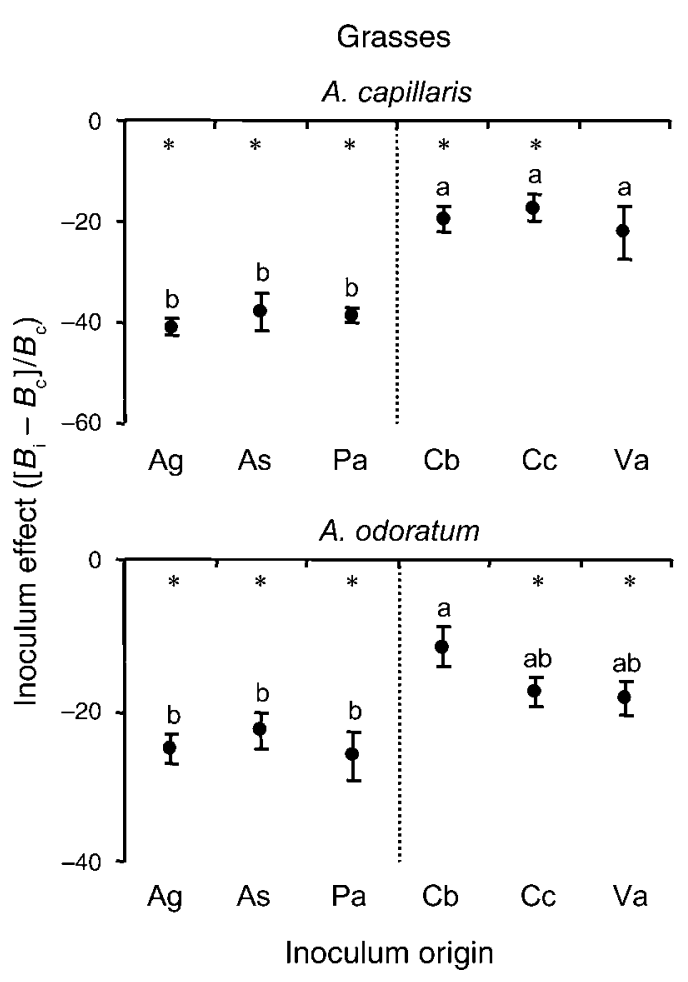

\section{DisCUSSION}

Biotic plant-soil feedback effects are known to influence plant performance and competitive ability (Van der Putten et al. 1993, Bever 1994, Van der Putten and Peters 1997). Our results show that plant-soil feedback dynamics in pioneer stages of secondary succession result in a historical contingency effect that can enhance the rate of succession to later-successional

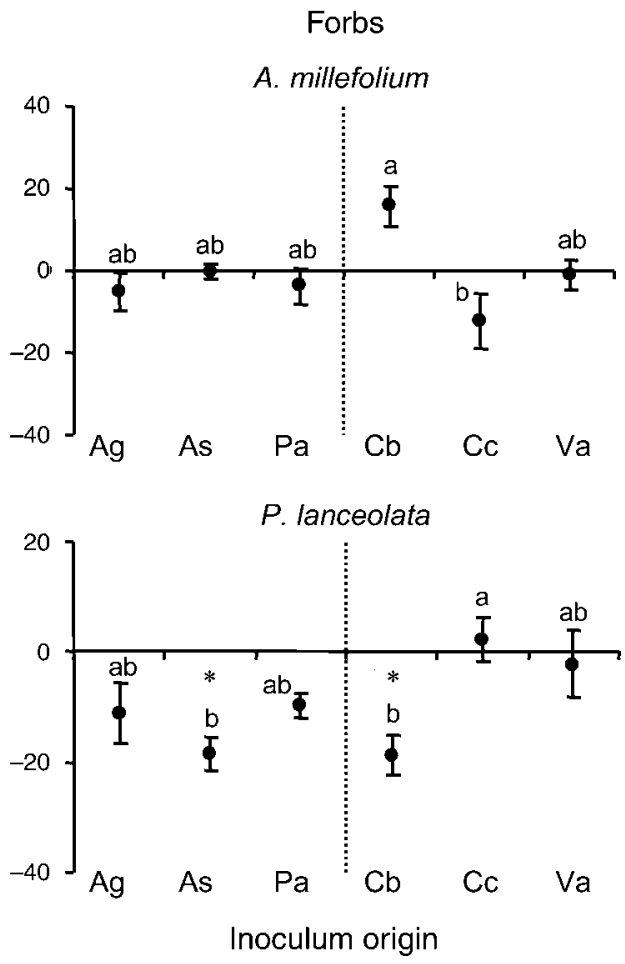

FIG. 5. Biomass production (mean $\pm \mathrm{SE}$ ) of mid-successional grasses (left-hand panels) and forbs (right-hand panels) in soil with microbial inocula relative to soil without these inocula. The inocula originated from soils with histories of early-successional plant species, as indicated by the first letters of genus and species names (abbreviations are the same as in Fig. 4). Asterisks indicate an inoculum effect significantly different from zero (Bonferroni-adjusted $t$ tests, $P<0.05$ ). Different lowercase letters denote significant differences between means (one-way ANOVA, Tukey post hoc tests, $P<0.05$ ). Dotted vertical lines divide between inocula originating from grasses $(\mathrm{Ag}, \mathrm{As}, \mathrm{Pa})$ and forbs $(\mathrm{Cd}, \mathrm{Cc}, \mathrm{Va})$. Scale numbers on the $y$-axis represent the reduction effect measured as percentage change in biomass. 
TABLE 2. Relationship between biomass production of Poa annua (root, shoot, and total) and microbial rhizosphere community composition.

\begin{tabular}{|c|c|c|c|c|c|c|c|c|}
\hline \multirow[b]{3}{*}{ Biomass } & \multicolumn{4}{|c|}{ Fungal profile } & \multicolumn{4}{|c|}{ Bacterial profile } \\
\hline & \multicolumn{2}{|c|}{ First PCA axis } & \multicolumn{2}{|c|}{ Second PCA axis } & \multicolumn{2}{|c|}{ First PCA axis } & \multicolumn{2}{|c|}{ Second PCA axis } \\
\hline & $R^{2}$ & $P$ & $R^{2}$ & $P$ & $R^{2}$ & $P$ & $R^{2}$ & $P$ \\
\hline Root & 0.040 & 0.25 & 0.006 & 0.65 & 0.006 & 0.66 & 0.006 & 0.66 \\
\hline Shoot & 0.189 & 0.01 & 0.174 & 0.01 & 0.003 & 0.93 & 0.063 & 0.15 \\
\hline Total & 0.130 & 0.03 & 0.084 & 0.09 & 0.001 & 0.87 & 0.036 & 0.28 \\
\hline
\end{tabular}

Note: Relationships were tested with linear regression using first and second axis sample scores derived from principal components analysis (PCA) on bacterial and fungal denaturing gradient gel electrophoresis profiles.

plant communities. The legacy effects of the earlysuccessional plant species on the soil microbial community have long-lasting effects, which may influence plant performance and population dynamics in further stages of secondary succession. Therefore plant community dynamics at any stage of ecosystem development may in part reflect soil community influences from the past. These results are of major importance to better understand the dynamics in natural plant communities.

Biomass production of early-successional plants was significantly reduced in soil that had been cultured by conspecifics compared to soil that had been cultured by heterospecifics. These negative plant-soil feedback effects could arise when the presence of specific plant roots or root exudates cause selective increase in the density of selective, or host-specific, pathogens. These pathogens will have overwhelmed potential beneficial effects of rhizobacteria and arbuscular mycorrhizal fungi. For common grassland species, such feedbacks from the soil community to individual plant species have been suggested to result from a buildup of pathogenic soil bacteria and fungi (Bever 1994, Mills and Bever 1998, Holah and Alexander 1999, Westover and Bever 2001). The "blackbox approach" of our feedback experiment did not allow us to identify the components of the soil community responsible for the observed biomass patterns. However, consistent with previous studies, and also in our experiment, the plant-soil feedback effects were most likely attributable to plantspecific shifts in microbial soil communities, as the results of the microbial inocula (experiment 2) were quite consistent with the feedback responses in whole soil (experiment 1). This does not exclude the role of other agents, such as nematodes (Olff et al. 2000, De Deyn et al. 2003) or other invertebrates (Gange and Brown 2002, De Deyn et al. 2003), but it shows that in soil, different taxonomic groups of organisms may have similar effects.

Alternatively, the observed plant-soil feedback effects could have been the result of changes in abiotic soil properties (Berendse 1998). However, starting from soil with low organic matter content minimized potential differences in decomposition and mineralization. Moreover, differences in plant composition and biomass production between home and foreign soil treatments in the first stage of the experiment (Appendix E) could not explain observed reductions in biomass production. Additionally, nutrient concentrations in the inocula were low, and the amount of nutrients added by the inocula relative to the total amount of available nutrients was marginal ( $<5 \%$; Appendix $C)$. This supports our hypothesis that plant-specific changes in soil microorganism communities were involved in the observed feedback effects rather than changes in the availability of soil nutrients (Bezemer et al. 2006).

Molecular analysis of the rhizosphere community of Pоа аппиа pointed at plant-specific shifts in the fungal soil community as influenced by plant history. DGGE analyses were variable within treatments, but they suggested a relationship between plant biomass production and the composition of the dominant fungal species that were present in the rhizosphere. However, the causality needs further experimental exploration, which should also explain why the relationship between biomass production and the composition of the fungal rhizosphere community was stronger for shoot biomass than for root biomass. Bacterial profiles did not show any clear patterns; moreover, microbial community profiles of the rhizosphere showed low similarities with the corresponding inocula profiles. Both fungal and bacterial DGGE profiles of the sterilized control treatments contained detectable bands as well, which is due to recolonization of the sterilized soil by airborne microorganisms. Part of the observed variation in rhizosphere profiles, therefore, was not due to the inocula treatments. Furthermore, DGGE profiles may not include all microorganisms present (Van der Wal et al. 2006a), and they do not discriminate between pathogens and nonpathogens. Therefore classical isolation and enumeration studies are needed as a follow-up in order to detect candidate pathogens.

Our results show that the soil pathogens were selective, but probably not strongly host specific. The (partial) biomass reduction of the early-successional species Alopecurus geniculatus, Apera spica-venti, Pоа аппиа, and Conyza canadensis by heterospecific inocula suggests that there were also more generalist pathogens involved. Nonspecific plant-pathogen associations may manifest themselves frequently aboveground (Burdon 1987), and for soil pathogens it has been suggested that they were predominantly generalistic (Jarosz and Davelos 1995). Our inoculation experiment clearly shows that the 
observed effects were due to combinations of more and less selective (or host specific) effects, which differed among plant species. This conclusion is supported by the differential responses of the early-successional plant species to heterospecific inocula. These results might have been, at least in part, the result of plant-specific differences in the susceptibility to nonspecific soil pathogens (Burdon 1987). Interestingly, the only species that did not respond disproportionately to its own soil community was $C$. canadensis, which is a nonnative plant species originating from northern America. In another study, nonnative plant species have shown neutral to positive soil feedback effects (Klironomos 2002), so that our results support the possibility of release from soilborne enemies of exotic plant species in their nonnative range (Klironomos 2002, Callaway et al. 2004).

For Capsella bursa-pastoris, we observed marked discrepancy between its feedback effect in experiment 1 and the respective inoculum effects in experiment 2. C. bursa-pastoris showed a strong negative feedback effect, whereas the conspecific microbial inoculum did not result in reduced biomass production. Apparently the feedback effect of $C$. bursa-pastoris may not have been caused by plant-specific accumulation of pathogenic soil bacteria and fungi. Most likely, other candidates, such plant-parasitic nematodes (Van der Putten et al. 1993, Olff et al. 2000), pathogenic effects caused by mycorrhizal fungi (Bever 2002), or synergistic effects between different groups of pathogens (De Rooijvan der Goes et al. 1998) have been involved in the feedback response of C. bursa-pastoris. We did not establish if the remaining roots may have released growth-reducing allelopathic compounds (Singh et al. 1999). Alternatively, some of the potential pathogens may have been susceptible to the procedure of collecting and inoculating the soil microbial inocula. Since nutrient availability was high (Appendix C), we do not assume competition for nutrients between plants and soil microorganisms (Kaye and Hart 1997) to have influenced the results of our experiment.

Earlier studies on plant-soil feedback (Van der Putten et al. 1993, Bever 1994, Klironomos 2002) paid little attention to the implications of early-successional plantsoil feedback effects for long-term plant community assembling processes. Our results show two possible mechanisms by which early-successional plant-soil feedbacks can affect plant succession. First, negative plant-soil feedbacks were most pronounced when plants were grown in competition with heterospecifics, pointing at soil pathogens involved as an apparent factor in interspecific plant competition, thereby enhancing competitive displacement of early-successional species by their successors (Van der Putten and Peters 1997). Enhanced feedback effects in competition with heterospecifics could not be explained by differences in total biomass production or production of the heterospecifics. Our experimental design did not allow us to ascribe differences in feedback responses of early-successional species between monocultures and mixed communities to interspecific competition from mid-successional species in particular. Enhanced feedback effects due to competitive interactions, and subsequent changes in dominance patterns, may be observed within successional stages as well.

Second, we showed that the legacy effect of feedback between plants and soil biota have much longer-lasting effects on plant community development than previously supposed (Van der Putten et al. 1993, De Deyn et al. 2003). In the feedback experiment, plant history had a significant effect on dominance patterns of the midsuccessional species in the mixed plant communities. For example, mid-successional grasses performed less well when preceded by monocultures of early-successional grasses. We could not consider effects of soil history on mid-successional species separate from the actual presence of the early-successional species. However, the corresponding responses of the mid-successional plant species to the microbial inocula from monocultures of the early-successional plant species showed that soil microorganisms may, at least in part, explain the ecological legacy effects of the soil (Swanson and Franklin 1992). Both the inoculation experiment and the feedback experiment indicate that, among an array of plant-specific effects, the legacy effects of earlysuccessional grasses on mid-successional grasses through soil microbial community development were more pronounced than effects on forbs. However, other studies show plant-induced effects on soil community composition for forbs as well (De Deyn et al. 2004, Van Ruijven et al. 2005), and when using mixed model analysis with random factors, the grass effects were only marginally significant, indicating that more studies are needed in order to allow more general conclusions on guild shifts in ecosystem succession.

The potential of applying the concept of microbemediated plant-soil feedback in restoration ecology remains tentative (Young et al. 2005, Kardol et al. 2006). Agricultural history may strongly affect initial composition of the soil community at the start of land abandonment (Girvan et al. 2004). Variability in agricultural land use may therefore give rise to disparate plant-soil feedbacks for early-successional plants and hence variable effects on later-successional plant community development. While specific plant properties can have a selective effect on the organisms they accumulate in their rhizosphere (Kowalchuk et al. 2002), the abundance and composition of the soil community can be considered as the regional species pool that strongly affects the local community structure in the rhizosphere (De Ridder-Duine et al. 2005). Selective amplification of the soil community by plant roots consequently influences plant-soil feedback effects to both the offspring of the initial colonizer and to the later succession species. In contrast to primary succession, for secondary succession after land abandonment this suggests potential strong legacy effects of the former land use. 


\section{CONClusion}

Traditionally, life history traits, such as propagule arrival and establishment, growth, and longevity, have been assumed to sufficiently account for the pattern and endpoint of successional change without invoking an important role for any biological interactions (Egler 1954, Noble and Slatyer 1980, Walker et al. 1986). Biological interactions were proposed to be more important in determining the rate of succession than its final outcome (Walker and Chapin 1987, Kardol et al. 2006). Here we show that plant-soil feedback effects in early stages of secondary succession enhance the rate of species replacement and, most importantly, that they provide a biotic legacy effect resulting in altered patterns of dominance in mid-succession plant communities. Our results imply that stochastic colonization of early-successional plant species (i.e., initial species composition), through ecological legacy of plant soil-feedbacks, could lead to historical contingent effects in later successional plant community assembly (White and Jentsch 2004). Further studies are needed to determine how these historical contingency effects influence not only the rate but also the direction of succession.

\section{ACKNOWLEDGMENTS}

We thank Martijn Bezemer for useful comments throughout the experiment, Wiecher Smant for technical assistance, and Arjen Biere and Koen Verhoeven for their excellent help with the statistical analyses. This study was funded by TRIAS-SKB (Grant 835.80.113). Publication 3949 Netherlands Institute of Ecology (NIOO-KNAW).

\section{Literature Cited}

Ames, R. N., K. L. Mihara, and G. J. Bethlenfalvay. 1987. The establishment of micro-organisms in vesicular-arbuscular mycorrhizal and control treatments. Biology and Fertility of Soils 3:217-223.

Bardgett, R. D., W. D. Bowman, R. Kaufmann, and S. K. Schmidt. 2005. A temporal approach to linking aboveground and belowground ecology. Trends in Ecology and Evolution 20:634-641.

Bardgett, R. D., and A. Shine. 1999. Linkages between plant litter diversity, soil microbial biomass and ecosystem function in temperate grasslands. Soil Biology and Biochemistry 31: 317-321.

Bartelt-Ryser, J., J. Joshi, B. Schmid, H. Brandl, and T. Balser. 2005. Soil feedbacks of plant diversity on soil microbial communities and subsequent plant growth. Perspectives in Plant Ecology Evolution and Systematics 7:27-49.

Berendse, F. 1998. Effects of dominant plant species on soils during succession in nutrient-poor ecosystems. Biogeochemistry $42: 73-88$.

Bever, J. D. 1994. Feedback between plants and their soil communities in an old field community. Ecology 75:1965-1977.

Bever, J. D. 2002. Negative feedback within a mutualism: hostspecific growth of mycorrhizal fungi reduces plant benefit. Proceedings of the Royal Society B 269:2595-2601.

Bever, J. D. 2003. Soil community feedback and the coexistence of competitors: conceptual framework and empirical tests. New Phytologist 157:465-473.

Bever, J. D., K. M. Westover, and J. Antonovics. 1997. Incorporating the soil community into plant population dynamics: the utility of the feedback approach. Journal of Ecology 85:561-573.
Bezemer, T. M., G. B. De Deyn, T. M. Bossinga, N. M. van Dam, J. A. Harvey, and W. H. van der Putten. 2005. Soil community composition drives aboveground plant-herbivore-parasitoid interactions. Ecology Letters 8:652-661.

Bezemer, T. M., C. S. Lawson, K. Hedlund, A. R. Edwards, A. J. Brook, J. M. Igual, S. R. Mortimer, and W. H. van der Putten. 2006. Plant species and functional group effects on abiotic and microbial soil properties and plant-soil feedback responses in two grasslands. Journal of Ecology 94:893-904.

Bonanomi, G., F. Giannino, and S. Mazzoleni. 2005. Negative plant-soil feedback and species coexistence. Oikos 111: 311-321.

Bonanomi, G., and S. Mazzoleni. 2005. Soil history affects plant growth and competitive ability in herbaceous species. Community Ecology 6:23-28.

Brown, V. K., and A. C. Gange. 1990. Insect herbivory below ground. Advances in Ecological Research 20:1-58.

Brown, V. K., and A. C. Gange. 1992. Secondary plant succession: how is it modified by insect herbivory? Vegetatio 101:3-13.

Bruehl, G. W. 1987. Soilborne plant pathogens. Macmillan, New York, New York, USA.

Burdon, J. J. 1987. Diseases and plant population biology. Cambridge studies in ecology. Cambridge University Press, Cambridge, UK.

Callaway, R. M., G. C. Thelen, A. Rodriguez, and W. E. Holben. 2004. Soil biota and exotic plant invasion. Nature 427:731-733.

Chanway, C. P., R. Turkington, and F. B. Holl. 1991. Ecological implications of specificity between plants and rhizosphere micro-organisms. Advances in Ecological Research 21:121-169.

Chapin, F. S., L. R. Walker, C. L. Fastie, and L. C. Sharman. 1994. Mechanisms of primary succession following deglaciation at Glacier Bay, Alaska. Ecological Monographs 64:49175.

Coley, P. D., J. P. Bryant, and F. S. Chapin. 1985. Resource availability and plant anti-herbivore defense. Science 230: 895-899.

De Deyn, G. B., C. E. Raaijmakers, J. van Ruijven, F. Berendse, and W. H. van der Putten. 2004. Plant species identity and diversity effects on different trophic levels of nematodes in the soil food web. Oikos 106:576-586.

De Deyn, G. B., C. E. Raaijmakers, H. R. Zoomer, M. P. Berg, P. C. de Ruiter, H. A. Verhoef, T. M. Bezemer, and W. H. van der Putten. 2003. Soil invertebrate fauna enhances grassland succession and diversity. Nature 422:711-713.

De Ridder-Duine, A. S., G. A. Kowalchuk, P. KleinGunnewiek, W. Smant, J. A. van Veen, and W. de Boer. 2005. Rhizosphere bacterial community composition in natural stands of Carex arenaria (sand sedge) is determined by bulk soil community composition. Soil Biology and Biochemistry 37:349-357.

De-Rooij-van der Goes, P., B. A. M. Peters, and W. H. van der Putten. 1998. Vertical migration of nematodes and soil-borne fungi to developing roots of Ammophila arenaria (L.) link after sand accretion. Applied Soil Ecology 10:1-10.

Dobson, A., and M. Crawley. 1994. Pathogens and the structure of plant communities. Trends in Ecology and Evolution 9:393-398.

Egler, F. E. 1954. Vegetation science concepts I. Initial floristic composition. A factor in old-field vegetation development. Vegetatio 4:412-417.

Gange, A. C., and V. K. Brown. 2002. Soil food web components affect plant community structure during early succession. Ecological Research 17:217-227.

Girvan, M. S., J. Bullimore, A. S. Ball, J. N. Pretty, and A. M. Osborn. 2004. Responses of active bacterial and fungal communities in soils under winter wheat to different fertilizer and pesticide regimens. Applied and Environmental Microbiology 70:2692-2701. 
Grime, J. P. 2001. Plant strategies, vegetation processes and ecosystem properties. Wiley and Sons, Chichester, UK

Hättenschwiler, S., A. V. Tiunov, and S. Scheu. 2005. Biodiversity and litter decomposition in terrestrial ecosystems. Annual Review of Ecology, Evolution, and Systematics 36:191-218.

Herms, D. A., and W. J. Mattson. 1992. The dilemma of plants: to grow or defend. Quarterly Review of Biology 67:283-335.

Heuer, H., K. Hartung, G. Wieland, I. Kramer, and K. Smalla. 1999. Polynucleotide probes that target a hypervariable region of $16 \mathrm{~S}$ rRNA genes to identify bacterial isolates corresponding to bands of community fingerprints. Applied and Environmental Microbiology 65:1045-1049.

Heuer, H., M. Krsek, P. Baker, K. Smalla, and E. M. H. Wellington. 1997. Analysis of actinomycete communities by specific amplification of genes encoding 16S rRNA and gelelectrophoretic separation in denaturing gradients. Applied and Environmental Microbiology 63:3233-3241.

Holah, J. C., and H. M. Alexander. 1999. Soil pathogenic fungi have the potential to affect the co-existence of two tallgrass prairie species. Journal of Ecology 87:598-608.

Jarosz, A. M., and A. L. Davelos. 1995. Effects of disease in wild plant-populations and the evolution of pathogen aggressiveness. New Phytologist 129:371-387.

Kardol, P., T. M. Bezemer, and W. H. van der Putten. 2006. Temporal variation in plant-soil feedback controls succession. Ecology Letters 9:1080-1088.

Kardol, P., T. M. Bezemer, A. van der Wal, and W. H. van der Putten. 2005. Successional trajectories of soil nematode and plant communities in a chronosequence of ex-arable lands. Biological Conservation 126:317-327.

Kaye, J. P., and S. C. Hart. 1997. Competition for nitrogen between plants and soil micro-organisms. Trends in Ecology and Evolution 12:139-143.

Keever, C. 1950. Causes of succession on old fields of the Piedmont, North Carolina. Ecological Monographs 20: 231-250.

Klironomos, J. N. 2002. Feedback with soil biota contributes to plant rarity and invasiveness in communities. Nature 417: 67-70.

Kowalchuk, G. A., D. S. Buma, W. de Boer, P. G. L. Klinkhamer, and J. A. van Veen. 2002. Effects of aboveground plant species composition and diversity on the diversity of soil-borne micro-organisms. Antonie van Leeuwenhoek International Journal of General and Molecular Microbiology 81:509-520.

Kowalchuk, G. A., and E. Smit. 2004. Fungal community analysis using PCR-denaturing gradient gel electrophoresis (DGGE). Pages 771-788 in G. A. Kowalchuk, F. J. de Bruijn, I. M. Head, A. D. L. Akkermans, and J. D. van Elsas, editors. Molecular microbial ecology manual. Kluwer Academic Publishers, Dordrecht, The Netherlands.

Mills, K. E., and J. D. Bever. 1998. Maintenance of diversity within plant communities: Soil pathogens as agents of negative feedback. Ecology 79:1595-1601.

Muyzer, G., E. C. Dewaal, and A. G. Uitterlinden. 1993. Profiling of complex microbial populations by denaturing gradient gel electrophoresis analysis of polymerase chain reaction-amplified genes coding for 16s ribosomal-RNA. Applied and Environmental Microbiology 59:695-700.

Noble, I. R., and R. O. Slatyer. 1980. The use of vital attributes to predict successional changes in plant communities subject to recurrent disturbances. Vegetatio 43:5-21.

Olff, H., B. Hoorens, R. G. M. de Goede, W. H. van der Putten, and J. M. Gleichman. 2000. Small-scale shifting mosaics of two dominant grassland species: the possible role of soil-borne pathogens. Oecologia 125:45-54.

Reynolds, H. L., A. Packer, J. D. Bever, and K. Clay. 2003. Grassroots ecology: plant-microbe-soil interactions as drivers of plant community structure and dynamics. Ecology 84: 2281-2291.

Singh, H. P., D. R. Batish, and R. K. Kohli. 1999. Autotoxicity: concept, organisms. Critical Reviews in Plant Sciences 18: 757-772.

Smith, S. E., and D. J. Read. 1997. Mycorrhizal symbiosis. Academic Press, London, UK.

Strong, D. R., H. K. Kaya, A. V. Whipple, A. L. Child, S. Kraig, M. Bondonno, K. Dyer, and J. L. Maron. 1996. Entomopathogenic nematodes: natural enemies of rootfeeding caterpillars on bush lupine. Oecologia 108:167-173.

Swanson, F. J., and J. F. Franklin. 1992. New forestry principles from ecosystem analysis of Pacific-Northwest forests. Ecological Applications 2:262-274.

Ter Braak, C. J. F., and P. Šmilauer. 1998-2002. Canoco for Windows 4.5. Biometris, Wageningen-UR, The Netherlands. Thrall, P. H., J. D. Bever, J. D. Mihail, and H. M. Alexander. 1997. The population dynamics of annual plants and soilborne fungal pathogens. Journal of Ecology 85:313-328.

Tilman, D. 1988. Plant strategies and the dynamics and structure of plant communities. Princeton University Press, Princeton, New Jersey, USA.

Vainio, E. J., and J. Hantula. 2000. Direct analysis of woodinhabiting fungi using denaturing gradient gel electrophoresis of amplified ribosomal DNA. Mycological Research 104: 927-936.

Van der Putten, W. H. 2003. Plant defense belowground and spatiotemporal processes in natural vegetation. Ecology 84 : 2269-2280.

Van der Putten, W. H., and B. A. M. Peters. 1997. How soilborne pathogens may affect plant competition. Ecology 78: 1785-1795.

Van der Putten, W. H., C. van Dijk, and B. A. M. Peters. 1993. Plant-specific soil-borne diseases contribute to succession in foredune vegetation. Nature 362:53-55.

Van der Wal, A., J. A. van Veen, A. S. Pijl, R. C. Summerbell, and W. de Boer. 2006a. Constraints on development of fungal biomass and decomposition processes during restoration of arable sandy soil. Soil Biology and Biochemistry 38: 2890-2902.

Van der Wal, A., J. A. van Veen, W. Smant, H. T. S. Boschker, J. Bloem, P. Kardol, W. H. van der Putten, and W. de Boer. $2006 b$. Fungal biomass development in a chronosequence of land abandonment. Soil Biology and Biochemistry 38:51-60.

Van Ruijven, J., G. B. De Deyn, C. E. Raaijmakers, F. Berendse, and W. H. Van der Putten. 2005. Interactions between spatially separated herbivores indirectly alter plant diversity. Ecology Letters 8:30-37.

Walker, L. R., and F. S. Chapin. 1987. Interactions among processes controlling successional change. Oikos 50:131-135.

Walker, L. R., J. C. Zasada, and F. S. Chapin. 1986. The role of life history processes in primary succession on an Alaskan floodplain. Ecology 67:1508-1523.

Wardle, D. A., G. W. Yeates, W. Williamson, and K. I. Bonner. 2003. The response of a three trophic level soil food web to the identity and diversity of plant species and functional groups. Oikos 102:45-56.

Westover, K. M., and J. D. Bever. 2001. Mechanisms of plant species coexistence: roles of rhizosphere bacteria and root fungal pathogens. Ecology 82:3285-3294.

White, P. S., and A. Jentsch. 2004. Disturbance, succession, and community assembly in terrestrial plant communities. Pages 342-366 in V. M. Temperton, R. J. Hobbs, T. Nuttle, and S. Halle, editors. Assembly rules and restoration ecology: bridging the gap between theory and practice. Island Press, Washington, D.C., USA.

Young, T. P., D. A. Petersen, and J. J. Clary. 2005. The ecology of restoration: historical links, emerging issues and unexplored realms. Ecology Letters 8:662-673. 
APPENDIX A

Abiotic soil characteristics at the start of the feedback experiment (Ecological Archives M077-005-A1).

\section{APPENDIX B}

Available nutrients in the sterilized soil and in the microbial inocula originating from soil in which monocultures of earlysuccessional plant species were grown in experiment 1 (Ecological Archives M077-005-A2).

\section{APPENDIX C}

Nutrient availability of soils in which monocultures of early-successional plant species were grown in experiment 1 (Ecological Archives M077-005-A3).

\section{APPENDIX D}

Temperature touch-down cycling programs for bacterial and fungal PCR (Ecological Archives M077-005-A4).

\section{APPENDIX E}

Shoot biomass per pot for monocultures and mixed communities in experiment 1 (Ecological Archives M077-005-A5).

\section{APPENDIX F}

Results of $t$ tests to analyze if feedback responses of early-successional plant species in monocultures and in mixed communities in competition with later-successional species differed from zero (Ecological Archives M077-005-A6).

\section{APPENDIX G}

Results of General Linear Model testing the difference in feedback effects of early-successional plant species in monocultures and in mixed communities in competition with later-successional species (Ecological Archives M077-005-A7).

\section{APPENDIX H}

Factor loadings of principal components analysis for mid-successional plant species grown in soil with histories of earlysuccessional plant species (Ecological Archives M077-005-A8).

\section{APPENDIX I}

Results of $t$ tests to analyze if inocula effects for early-successional plant species and mid-successional plant species differed from zero (Ecological Archives M077-005-A9).

\section{APPENDIX J}

Results from PROC MIXED (SAS) analysis of effects of inoculum origin on plant biomass production of mid-successional plant species relative to the sterilized control treatment (Ecological Archives M077-005-A10).

\section{APPENDIX K}

Ordination diagram of principal components analysis on bacterial and fungal denaturing gradient gel electrophoresis profiles of Poa annua rhizosphere samples (Ecological Archives M077-005-A11). 